\section{Н.В. Климова}

Тамбовский государственный музыкально-педагогический институт имени С.В. Рахманинова

2. Тамбов, Россия

ORCID: 0000-0002-2652-3024

nkliko68@mail.ru

\section{Nataliya V. Klimova}

Tambov State Musical Pedagogical

Institute named after S.V. Rachmaninov

Tambov, Russia

ORCID: 0000-0002-2652-3024

nkliko68@mail.ru

\section{Визуализация музыки как способ функционирования современного произведения: Эдисон Денисов, «Три картины Пауля Клее»}

\footnotetext{
Настоящая публикация представляет информационные и аналитические материалы к уроку в 7 классе детских музыкальных школ с комментариями и пояснениями живописной манеры немецкого художника Пауля Клее и авторского видения его полотен российским музыкантом XX века Эдисоном Денисовым. Рассматриваются вопросы визуализации как способа воздействия на восприятие современного академического музыкального произведения. Центральным разделом урока является анализ работ Клее (визуальный ряд) и анализ нотного текста цикла Денисова. Нотный текст и иллюстрации работ художника проецируются на экране, музыкальный поток накладывается на зрительное изображение. Таким образом, содержание камерного цикла Денисова постигается во взаимосвязи и через компоненты визуального способа функционирования произведения. Зрительный ряд в силу опыта синтетического восприятия искусства оказывает существенную помощь в обучении на начальном этапе музыкального образования. Выбор сочинения обусловлен обновлённым содержанием учебника для 7 класса детской музыкальной школы Ольги Аверьяновой «Отечественная музыка XX века» (М., 2014). В статье предлагается последовательное и взаимообусловленное рассмотрение
}

\section{Visualization of Music as a Means for the Contemporary Composition to Function: Edison Denisov, "Three Pictures by Paul Klee”}

This publication presents informational and analytic materials to a class in 7th grade of children's music schools with commentaries and elucidations of the artistic style of German artist Paul Klee and the personal perspective of his art works by 20th century Russian composer. Examination is made of the questions of visualization as a means of impact on the perception of a contemporary classical musical composition. The central portion of the class material is taken up by an analysis of Klee's works (the visual element) and the analysis of the musical score of Denisov's cycle. The musical score and the illustrations of the artist's works are projected on the screen, and the musical flow is superimposed on the visual depiction. Thereby, the content of Denisov's chamber cycle is comprehended in interconnection with and through the components of the visual means of the composition's functioning. As the result of the attempt of a synthetic perception of art, the visual element provides essential help in providing instruction at the elementary stage of musical education. The choice of the composition is stipulated by the revised content of the 7 th grade textbook for children's music schools by Olga Averyanova "Otechestvennaya muzyka XX veka” ["20th Century Russian Music”, Moscow, 2014]. The article suggests a consistent and interdependent examinations of the parameters of connections between 
параметров музыкально-живописных связей и отражение их в индивидуальном, сонорном потоке музыкальной композиции.

\section{Ключевые слова:}

Пауль Клее, Эдисон Денисов, камерный цикл «Три картины Пауля Клее», учебник для детской музыкальной школы «Отечественная музыка XX века», зрительный ряд в музыке, визуализация музыки. music and painting and their reflection in the individual, sonorous flow of the musical composition.

\section{Keywords:}

Paul Klee, Edison Denisov, the chamber cycle "Three Pictures by Paul Klee," the textbook for children's music schools "Otechestvennaya muzyka XX veka” [“20th Century Russian Music"], the visual element in music, visualization of music.

Для цитирования / For citation:

Климова Н.В. Визуализация музыки как способ функционирования современного произведения: Эдисон Денисов, «Три картины Пауля Клее» //

ИКОНИ / ICONI. 2019. № 4. С. 130-141.

DOI: 10.33779/2658-4824.2019.4.130-141.

$\mathrm{B}$ заимодействие музыки с визуальными искусствами имеет многовековую историю. Зрительные образы, полученные от созерцания художественного полотна или скульптуры, иногда инициируют замыслы композиторов. Таковы «Остров мёртвых» С. Рахманинова, созданный под впечатлением картины швейцарского художника A. Бёклина, фортепианный цикл М. Мусоргского «Картинки с выставки», написанный после выставки работ художника и архитектора В. Гартмана.

В начале XX века роль визуального фактора в музыкальном искусстве возрастает. Об этом свидетельствуют произведения К. Дебюсси, А. Шёнберга, И. Стравинского, О. Мессиана, а также С. Прокофьева, в сочинениях которого критики и аналитики усматривают скрытую «свёрнутую пластику» [4, с. 118]. Музыкальная культура второй половины XX и особенно XXI века тесно связала свою судьбу с техническим прогрессом, оказавшим огромное влияние на функционирование академического музыкального искусства. Возможно, это одна из причин, по которой современное композиторское творчество стало «наиболее открытым к аудиовизуальным технологиям" [2, с. 88].

Интенсивно развивающаяся визуализация академической музыки приводит к обновлению старых и образованию новых жанров, появлению электронных симфоний, концертов-перформансов, видеоинсталляций, рождению медиаоперы. Современное музыкальное искусство, как утверждает композитор Р. де Ман (Нидерланды), мыслится сегодня только в связях с визуальными искусствами и особенно - видеотехнологиями ${ }^{1}$.

Возрастающий интерес отечественной композиторской практики к аудиовизуальным технологиям всё яснее очерчивает круг задач, стоящих и перед педагогами начального музыкального образования. Одна из них - ввести школьников в музыкальную среду современности и в доступной и интересной форме донести смысл и содержание произведений ныне творящих авторов. Сделать это не всегда просто, но возможно, используя обновлённые формы наглядного метода преподавания музыкальной литературы в 7 классе ДМШ, когда школьники зна- 
комятся с произведениями Э. Денисова, С. Губайдулиной, А. Шнитке, С. Слонимского, Б. Тищенко.

За последние десять лет содержание предмета «Музыкальная литература» в школе кардинально обновилось. Отметим, прежде всего, учебник О.А. Аверьяновой $[1]^{2}$. В нём впервые школьники получают информацию о композиторской технике XX века, в том числе об алеаторной, сонорной и электронной музыке. Сложность «общения» с такого рода информацией можно преодолеть, если обратиться к визуальным средствам, используя на уроках видеоиллюстрации. Достижения современной техники - аудио и видео - предоставляют возможности выявления более тесного взаимодействия изображения с музыкой. В выпускном классе школы средства визуализации способны подготовить учеников к восприятию современного музыкального произведения, создать условия для его понимания как органичного целого.

Отметим, что в современной концертной практике визуализация - проектирование связи музыкального произведения с живописными полотнами или графикой художников - один из эффективных способов привлечения внимания слушателей, их подготовки к прослушиванию современного музыкального произведения. Поэтому нередко ведущие концертов, лекторы, комментаторы обращаются к визуальным средствам. Однако эффективность и действенность визуальных средств проявляются при условии, если их организация отражает изначальную направленность музыкального произведения на взаимодействие с другими искусствами. И это взаимодействие должно быть обусловлено программой сочинения или аннотируемыми композитором образными ассоциациями. В школьном курсе музыкальной литературы дети постепенно приобретают опыт общения с программными произведениями через элементы языка других искусств. Начиная с сочинений композиторов-романтиков (например, песня «Гретхен за прялкой» Шуберта, сюита «Пер Гюнт» Грига), в русской музыке - с произведений Мусоргского, Римского-Корсакова, Скрябина, Стравинского и Прокофьева школьники накапливают богатый опыт знаний и восприятия такого рода сочинений.

Рассмотрим более подробно один из примеров такого знакомства учащихся 7 класса с циклом Э. Денисова «Три картины Пауля Клее», рекомендованным учебником О. Аверьяновой. Это новое для восприятия школьников произведение оказывается доступным в связи с привлечением аудиовизуальных средств, содержащих нотный текст цикла и изображение картин Пауля Клее. Сочинение прослушивается школьниками, одновременно наблюдающими нотный текст после краткого знакомства с видеорядом картин художника. Совокупность аудио- и видеорядов помогает восприятию, пониманию художественных задач, стоящих перед слушателями. С помощью сравнительного анализа, выявление сходства и отличия элементов музыкального и живописного языка, содержание музыкального произведения становится более доступным учащимся.

На занятиях школьники получают информацию о личности композитора, узнают, что Эдисон Васильевич Денисов (1929-1996) - «классик» современной отечественной музыки, один из музыкантов, на которого особенно сильное воздействие оказывали визуальные искусства и, в том числе живопись, графика.

Денисов высоко ценил в своей музыке цвет и свет и наблюдал способы их воплощения в живописи. Замыслы произведений, светозвуковые решения были неоднократно подсказаны композитору увиденными полотнами художников. Таково оркестровое произведение «Живопись» (1970), написанное по картине 


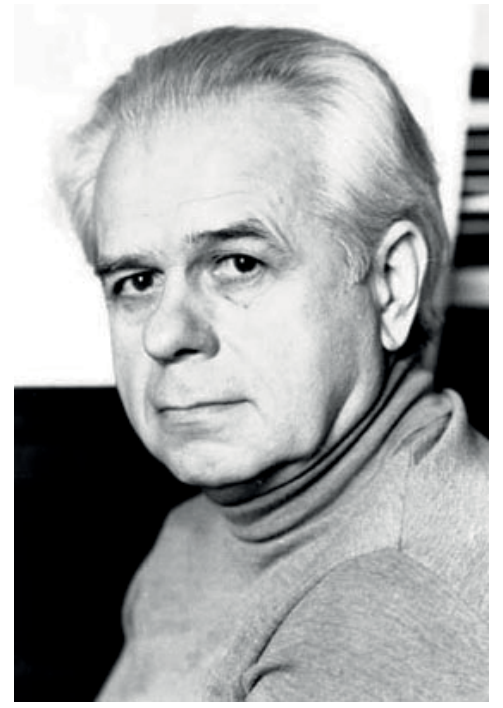

Фото 1. Эдисон Денисов

«Красная комната» петербургского художника Бориса Биргера (1923-2001); «Женщина и птицы» (1996) для фортепиано и двух квартетов - струнного и деревянных духовых инструментов, созданное под впечатлением картин испанского живописца и скульптора Хуана Миро (1893-1983). Живописные ассоциации возникают в названиях отдельных произведений Денисова, например, «Акварели» (1975) для 24 струнных инструментов, «Зимний пейзаж» для арфы, «Перед закатом» (1996) для альтовой флейты и вибрафона. Некоторые из сочинений по названиям напоминают об импрессионистических образах Дебюсси: «Колокола в тумане» (1988) для оркестра, «Пейзаж в лунном свете» для кларнета и фортепиано, «Мёртвые листья» (1980) для клавесина, «Отражения» (1989) для клавесина и ударных, «На пелене застывшего пруда» (1991) для девяти инструментов и магнитофона, «Точки и линии» (1988) для двух роялей в 8 рук. Цветовой спектр отражают такие опусы, как «Жизнь в красном цвете», «Знаки на белом», «Чёрные облака», «Голубая тетрадь», «Лучи далёких звёзд в искривлённом пространстве» и другие ${ }^{3}$.

Но творчество швейцарского художника Пауля Клее (1879-1940) оказалось особенно близко композитору. Влияние
Клее испытали многие современные музыканты, среди которых - китайский и американский композитор Тан Дун, написавший оркестровую пьесу «Огонь и Смерть. Диалоги с Паулем Клее» по одной из последних картин художника. А также фортепианная пьеса Б. Йоффе "Angelus novus», созданная по одноимённой картине художника. Имя мастера навсегда запечатлено в знаменитом стихотворении А. Тарковского «Пауль Клее».

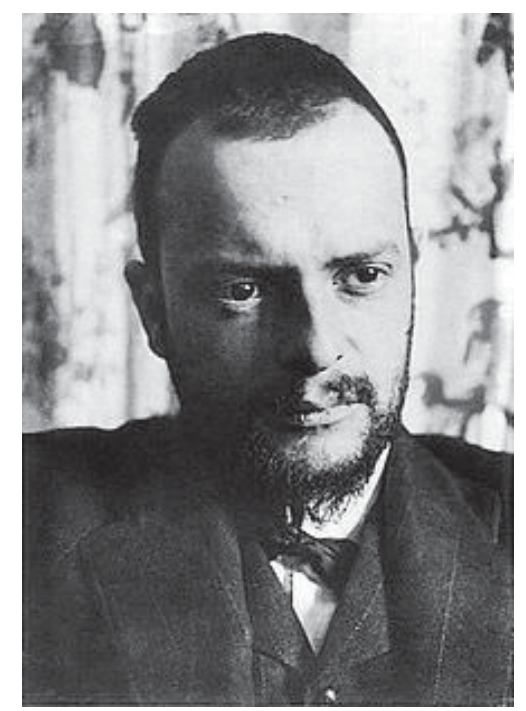

Фото 2. Пауль Клее

График, живописец, педагог, Клее с детства испытывал влечение к поэзии, литературе и особенно к музыке. И хотя его профессиональным поприщем стало изобразительное искусство, преданность музыке он сохранил на всю жизнь. Талантливый скрипач (он окончил консерваторию в Швейцарии), в трудные годы Клее подрабатывал, играя в оркестре. Музыкой, её ритмами проникнуто большинство работ художника. Стиль и композиция работ Клее рождается из линий, точек, пятен, «из хаоса», как отмечал художник в «Педагогических эскизах" [3]. Его картины являются результатом цветовой проекции, отражающей не сам предмет или пейзаж, а его глубинную подоснову. Творения Клее не становятся зеркальным отражением увиденного, а воспроизводят запредель- 
ный мир - мир зазеркалья. Это беспредметная живопись. Клее всегда верил, что изобразительное искусство «не передаёт только видимое, а делает зримым тайно постигнутое» [там же]. Как и в музыке, мир графики Клее полон таинств и очарования. Эти качества творчества художника были особенно близки Э.В. Денисову.

В 1985 году композитор создаёт цикл пьес для камерного ансамбля под названием «Три картины Пауля Клее». Это относительно небольшое сочинение для солирующего альта и ансамбля из пяти инструментов: гобоя, валторны, вибрафона, фортепиано и контрабаса. Произведение посвящено альтисту Большого театра Игорю Богуславскому. В цикле Денисова три части: "Диана в осеннем ветре», «Senecio», «Ребёнок на перроне». Живописному воплощению содержания цикла отвечает тембровая сторона сочинения. Композитор использует нетрадиционный состав инструментов, который меняется в каждой части. Так, в первой части звучат четыре инструмента из пяти: альт, фортепиано, вибрафон и контрабас, среди которых выделяется альт, исполняющий непродолжительные соло, а потому стоящий на сцене. Вторая часть «Senecio» поручена солирующему альту. Третья дополнена валторной и гобоем. Здесь альт не солирует, он - часть ансамбля. «Поэтому, - как отмечает Денисов, - я даже предпочитаю, чтобы в третьей части альтист не стоял, а сидел, как и все остальные музыканты» (цит. по: [5, с. 320]). «Тембр альта, - продолжает композитор, - как бы растворяется в общей краске, теряется среди других тембров. И, наоборот, в первой части у него есть довольно большая сольная каденция и дуэт с вибрафоном, и там же, и каденция самого вибрафона» [там же]. Отметим ещё развернутую партию контрабаса в «очень длинной коде», в которой используются «интересные краски натуральных флажолетов контрабаса в глиссандо и не глиссандо».
В первой части акцент делается как на ансамблевой манере высказывания, создающей эффект смешанных красок, так и на сольных выступлениях отдельных инструментов.

«То, что нас, музыкантов, больше всего влечёт в живописи, - говорил композитор, - это краска. В музыке - особенно в XX веке (после Мусоргского и особенно, после Дебюсси) - краска начала играть большую смысловую и выразительную роль. Это то, что нас роднит с живописью» [там же, с. 110]. Краска в музыкальном искусстве связывается с ладогармоническими, фактурными, тембровыми средствами выражения. В творчестве Денисова данные языковые параметры в совокупности составили неоспоримую индивидуальность почерка композитора. Это не привнесённые извне качества, а рождённые внутренним тембровым слухом музыканта, что позволяет говорить о природных, сонорных свойствах его музыки. Сонорика - техника звучностей - напрямую связана с красочными темброво-фактурными параметрами музыкального произведения, а приёмы её выражения имеют ассоциативные связи с визуальными искусствами, в данном случае с живописью П. Клее. Одна из задач, стоящая перед учащимися 7 класса,- - научиться различать на слух виды сонорных приёмов, и самое главное осознать их художественное предназначение. Цикл Денисова является классическим примером одной из таких сонорных композиций, которые часто называют «музыкальными картинами».

Стиль произведения Денисова близок живописному, и его цветовая палитра создана сонорными приёмами. Для выражения их в музыке часто используются определения: «колыхание», «переливы», "россыпи», «шорохи», "соноры дуновения», «лирическая вязь», что близко манере живописания Клее. О композиции частей цикла Денисов говорил, что он учился ей больше у живописцев, чем у композиторов, считая законы живописи 
идентичными музыкальным. Денисов, как и Клее, компоновал форму из суммы звуковых пятен различной окрашенности и различной интенсивности.

Первая часть "Диана в осеннем ветpe» создана под впечатлением картины Клее с аналогичным названием. Денисов уточняет, что на увиденном им полотне «в очень мягкой, слегка зеленоватой, краске угадывается изогнутый силуэт очень красивой женщины» [там же, c. 319]. Для Клее, мастера колорита, в данной картине форма рождается из гармонии цвета, из летящих, разноцветных мелких линий, напоминающих изображение несущейся по ветру листвы. Их пестроту нарушают контрастные по плотности цвета́, в которых проступает изломанный рельеф женской фигуры.

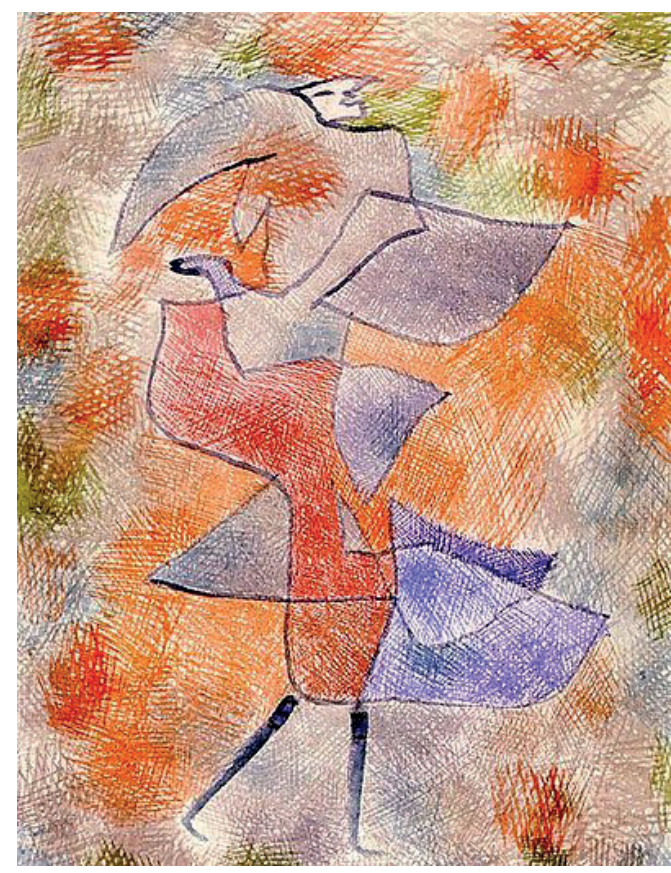

Ил. 1. "Диана в осеннем ветре», 1921

Он вырастает из красок цветного фона и слит с ним. Образ женщины, изображённой в воздушных движущихся линиях-потоках, коннотирует к мифологическому персонажу, олицетворяющему силы живой природы - богине Диане. Композиция первой части цикла Денисова вырастает из начального вибрирующего тона $A$ вибрафона, как из точки картины Клее. Это одна из музыкальных анаграмм Денисова: A = La - первая буква Lumière (фр.), Lux (лат.), что в переводе означает Свет. «Дрожание» тона ассоциируется с трепетанием лёгкого ветерка, с началом движения светоцветовой гаммы. Из тона формируются короткие мотивы альта, фортепиано, контрабаса, образующие непродолжительные по масштабам мелодические линии. Каждый инструмент имеет свою линию, которая не повторяется по ритму, мелодическому рисунку, часто по штриховым приёмам (в первой части используются четыре разных видов штриха). Тихое, мягкое звучание инструментов, преимущественно в высоком регистре (в том числе и контрабаса, партия которого записана в скрипичном ключе) и часто с сурдиной создают атмосферу утончённости, лёгкого прозрачного «колыхания» воздуха. Все процессы развития осуществляются без резких сдвигов за счёт постепенных внутренних изменений. Однако полиритмические наслоения мелодических узоров инструментов приводят к возникновению по горизонтали гармонических пятен или созвучий соноров. Это «мотивы дуновения», или «соноры дуновения». Они образуют контрапункты мягко ниспадающего или восходящего движения. В этих сквозных "мотивах-дуновениях" и украшающей всю музыкальную ткань трелеобразной мелизматике заключается таинство бесконечного движения силы воздушного потока.

В первой части цикла мотивы составляют фон, который оттеняет партии солирующих вибрафона, альта и в коде контрабаса. Мелодии солистов рождаются из сонорной гармонии фона и растворяются в ней. Особенно выделяется романтическая по характеру мелодия солирующего альта (первый раздел трёхчастной формы). По природе альт родствен скрипке, но отличается более густым тембром. Струны альта толще, а смычок тяжелее, чем у скрипки. Альт нотируется в альтовом и скрипичном 
ключах. Первое соло альта в цикле певучая, широкого диапазона мелодия, с причудливо изломанным рисунком - вносит оттенок мягкости, тепла, а легато сообщает плавность движения на фоне беспрерывного звучания трелей у остальных инструментов. Эта мелодия ассоциируется в представлении слушателей с образом Дианы. Мелодия вырастает из интервала уменьшённой терции (b-gis), который в других сочинениях часто связывается композитором с женскими образами (например, «Женщина и птицы»).

Bторая часть «Senecio», как утверждает композитор, - «это очень странный портрет человека, весь составленный из квадратов разного цвета: разноцветные глаза, которые смотрят в разные стороны, разноцветные части лица - во всём этом есть для меня что-то очень тревожное, очень напряжённое, неприятное это, как лицо “живой куклы”. Поэтому и в пьесе, в её музыке, есть и определённая жёсткость, и определённая нервность, и даже иногда как бы накапливается и при этом совсем не находит никакого выхода какая-то загадочная внутренняя напряжённость» [там же].

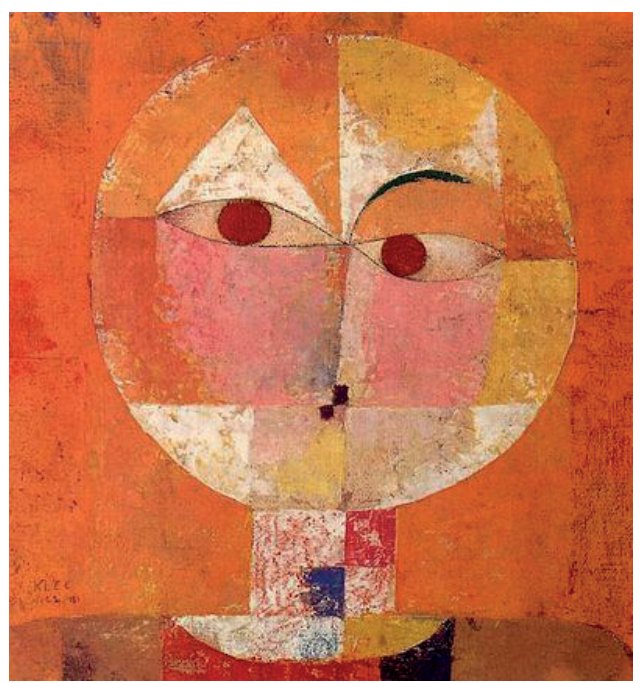

Ил. 2. «Sепесіо» («Сенечио»), 1922

На картине «Senecio» схематично изображено человеческое лицо в виде «разбитого» на разноцветные четырёх- угольники круга; в свою очередь, «лицо» вписано в квадрат и представляется своеобразной маской. Форма круга, его цветовое наполнение напоминают костюм итальянской уличной маски Арлекина. Известно, что «круг» в творчестве Клее является знаком целостности, с одной стороны, с другой - символом бесконечных перемещений (превращений), о чём свидетельствуют ряд других картин художника, в которых использована эта символическая форма: «Красная маска», «Лунный Пьеро», «Двойная Луна», «Чёрный князь» (их можно увидеть при прослушивании части цикла). Однако «Сенечио» - не застывшая маска; ассиметрия глаз, цветных квадратов свидетельствует о внутреннем движении, о скрытом мыслительном процессе. Во второй части цикла портрет персонажа воссоздаёт солирующий альт. Монотембр альта ассоциируется с целостностью. Но мелодическое начало здесь отступает на второй план, жёсткие многозвучные фигуры меняются как цветовые оттенки маски «Сенечио». С помощью штрихов, артикуляции, диссонантной интервалики, трелеобразных мотивов и свободного метра (в части отсутствуют тактовые черты) возникает психологическая картина контрастных смен состояний. Четыре раздела пьесы последовательно воплощают эту идею. Выразительные мотивы, которыми пронизано всё сочинение, ассоциируются по характеру с речью: жалобной, горькой, бессильной, замирающей в четвертитоновых трелях. В таких мотивах слышатся стоны Петрушки, Гнома, гневная и беспомощная речь Богатого и Бедного, как в пьесе Мусоргского. Таким образом, композитор воссоздаёт беспокойный внутренний мир персонажа (Molto inquieto - Беспокойно). Сочетания противоположностей разного свойства: фактурного, тесситурного, артикуляционного, гармонического и мелодического раскрывают эмоциональные коллизии «оживающей» маски. В небольшой коде, которая выполняет функцию ре- 
призы пьесы, звучность альта становится наиболее экспрессивной. Внутренний диалог инструмента подчёркнут сменой штрихов: sul ponticello (игра у подставки) на forte, fortissimo и ordinario на $p p$.

Последняя часть (учебником О. Аверьяновой рекомендовано прослушивание только первой части цикла) «Ребёнок на перроне» - «наиболее сюрреалистическая и наиболее страшная, - как пишет композитор. - Это пустой, чёрный, практически, мёртвый город и маленький ребёнок на железнодорожном перроне. Он весь в страхе, в ужасе, потому что весь город вокруг деформирован: все здания искажены, сдвинуты, сломаны - страшное состояние одиночества брошенного, забытого ребёнка» [там же, с. 320].

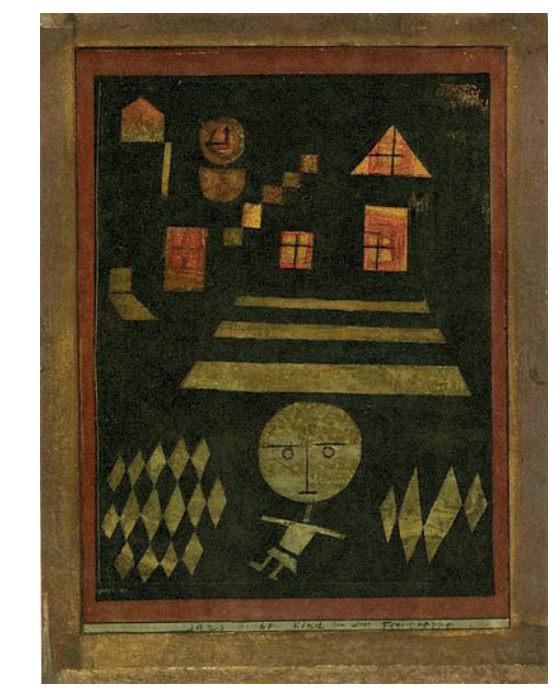

Ил. 3. «Ребёнок на перроне», 1923

Главная составляющая картины П. Клее - это "кричащая пустота» как выражение ужаса, одиночества ребёнка. Его падающая фигурка изображена на первом плане картины. Облик его не конкретен и по всем параметрам (голова в форме круга, дисгармония туловища) - тоже маска. Общий тон картины чёрный, безжизненный цвет пустоты, с вкраплением цветных пятен - бытовых примет вокзала. Пьеса Денисова, как и картина Клее, основана на приёмах искажения, что способствует выражению состояния страха. Денисов использует, прежде всего, нетипичные приёмы игры на инструментах: удары смычка контрабаса за подставкой, дребезжащий звук фортепиано в результате вставленного в струны шурупа. Отметим ещё «безжизненные» тембры валторны и гобоя, которые в традиционной классической музыке связаны с образами голосов природы или душевного человеческого тепла. Здесь же тембральная специфика инструментов трансформируется, ровные, «вытянутые» звуки инструментов ассоциируются с работой механизма, гулом удаляющегося в пространстве поезда. Недифференцированный звук без определённой высоты в партиях отдельных инструментов и плотная фактурная масса всех голосов ансамбля составляют мощное средство контраста, с помощью которого возникает тревожная атмосфера финала, его главная краска. По замечанию композитора, - «эта пьеса по языку наиболее жёсткая и нервная; много элементов серийности, гораздо больше, чем в двух других пьесах; и здесь же возникают частые и большие отстранения от звуков музыкальных - появляются звуки “неживые”, то есть намеренно искажённые, деформированные» [там же].

Таким образом, музыкальная интерпретация картин Пауля Клее в цикле Э. Денисова находит индивидуальные формы выражения, в которых важную роль играет сонорный фактор композиторской техники. Сам композитор утверждал, что его цикл есть «музыкальные аллюзии на живопись - иногда это только краска какая-то, близкая картине, а иногда это только какой-то момент общего движения, которое возникает тоже как аллюзия на движения в картине» [там же, с. 319]. Цикл является примером инструментальной программной сюиты XX века. Три контрастные по характеру и содержанию части представляют портреты трёх «персонажей», каждый из которых имеет свой эмоциональный мир, выраженный музыкальными средствами. 


\section{थ ПРИМЕЧАНИЯ}

1 Родерик де Ман (р. 1941, Нидерланды). Лекции, прочитанные в ТГМПИ имени С.В. Рахманинова. 12 декабря 2012.

2 Учебник дополняет аудиопособие, содержащее аналитический комментарий и запись рекомендованных для изучения произведений. См.: Аудиопособие по музыкальной литературе для 7 класса: 9 CD-ROM / текст Н.В. Климовой; ред. М.Б. Кушнир. М.: Ландграф, 2004.

3 Напомним об увлечении Денисова А. Матиссом, П. Мондрианом.

\section{थ НОТНОЕ ПРИЛОЖЕНИЕ $\longrightarrow$}

Пример № 1

э. Денисов. Три картины Пауля Клее.

Диана в осеннем ветре (№ 1)
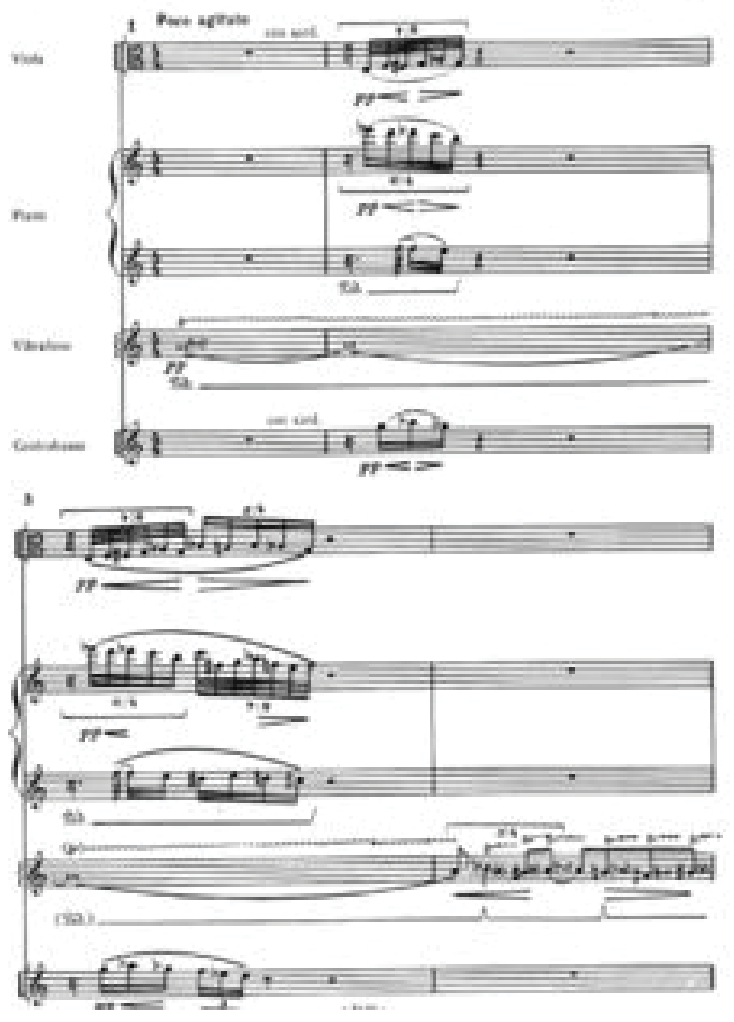
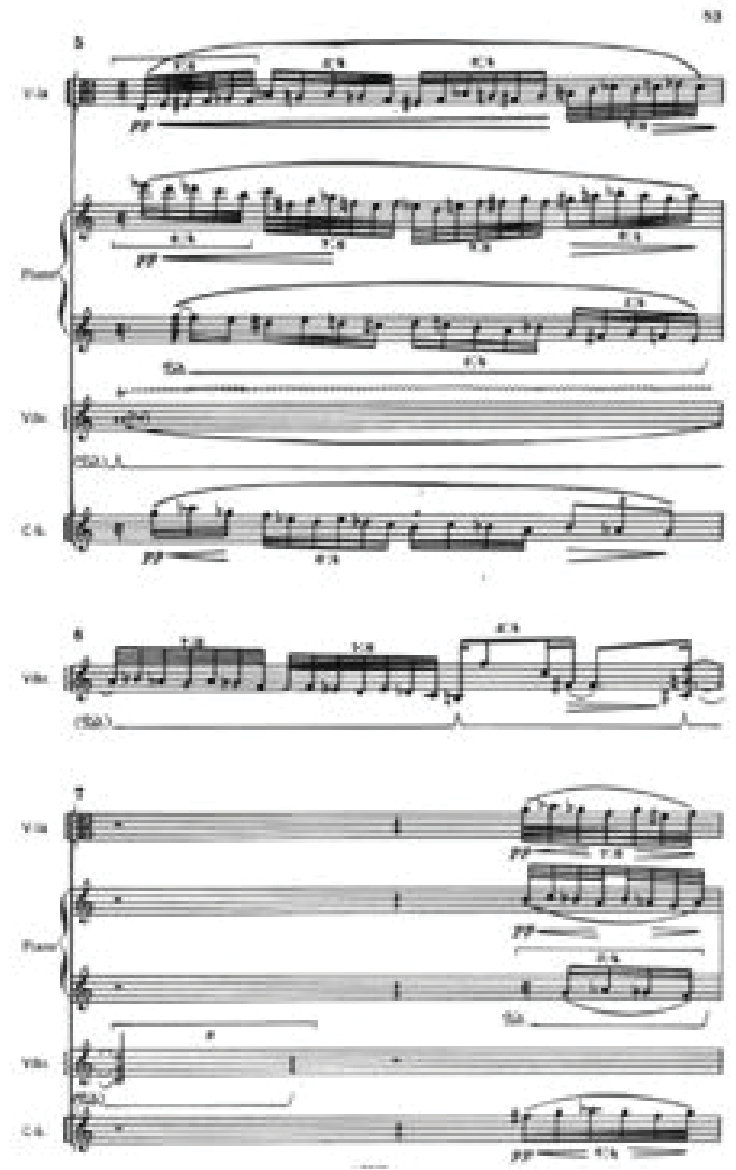
Пример № 2

Senecio (№ 2)

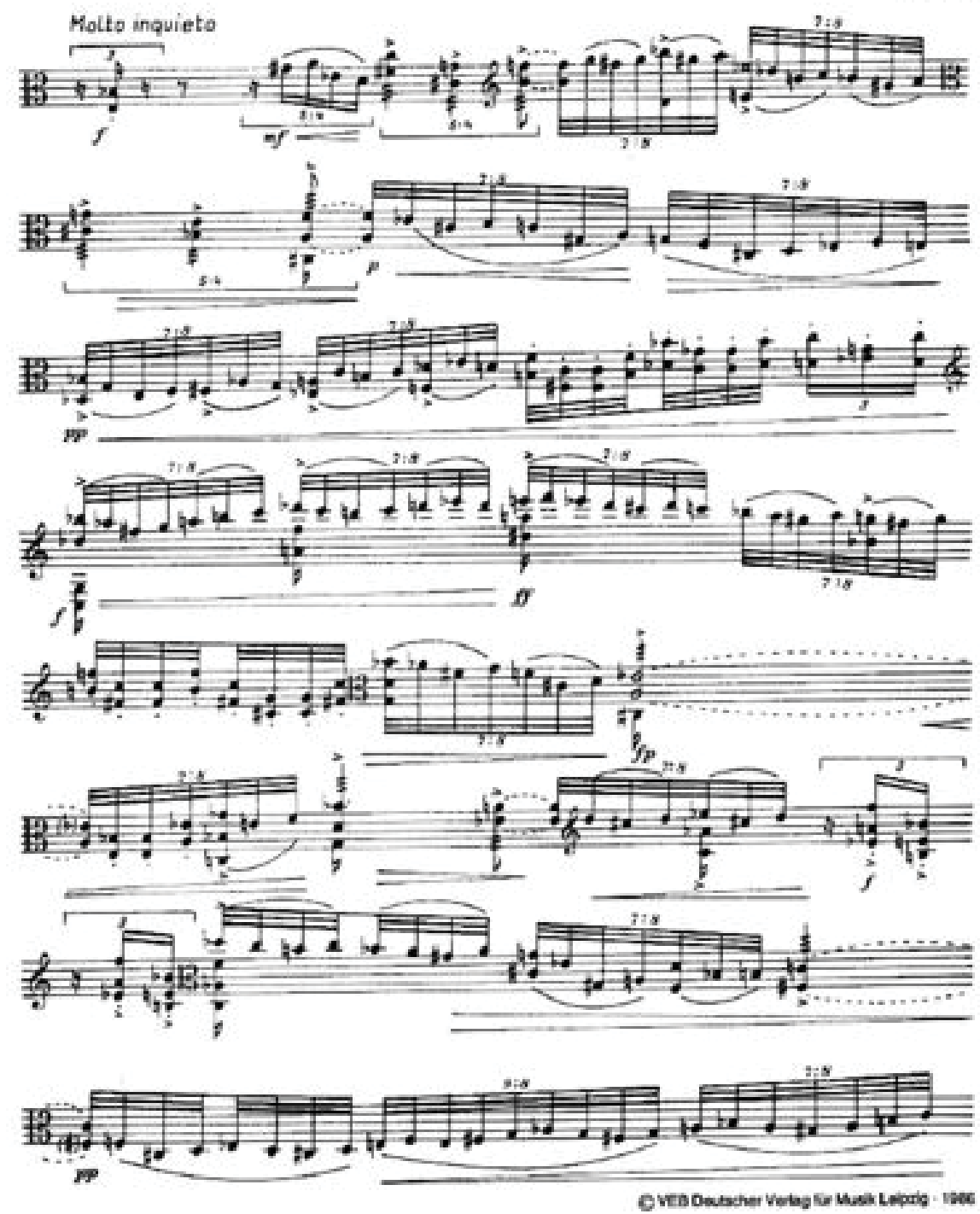


Пример № 3

Ребёнок на перроне (№ 3)

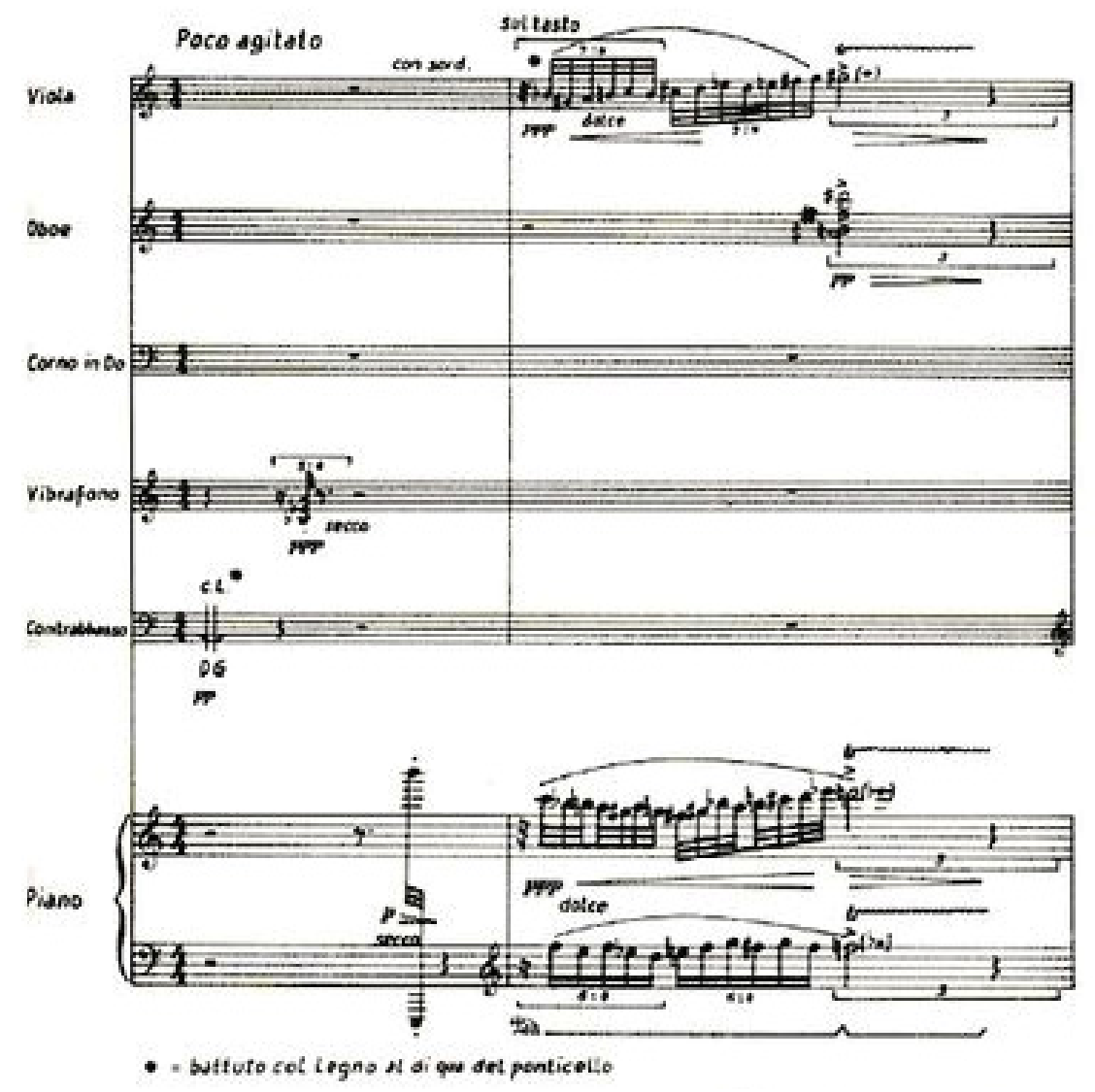

\section{литерАтурА $\sim$}

1. Аверьянова О.И. Отечественная музыкальная литература: учебник для детских музыкальных школ. Четвёртый год обучения. М.: Музыка, 2001. 254 с.

2. Жукова Т. Аудиовизуальные технологии в сфере современной академической музыки: тенденции, особенности, проблемы. Музыкальная жизнь. 2011. № 7/8. С. 88-90.

3. Клее П. Педагогические эскизы / пер. с нем. Н. Дружковой; под ред. Л. Монаховой; предисл. Л. Монаховой. М.: Изд-во Д. Аронов, 2005. 71 с.

4. Холопова В.Н. Музыка как вид искусства. 2-е изд. М.: Консерватория, 1990. 258 с.

5. Шульгин Д. И. Признание Эдисона Денисова. По материалам бесед. М.:

Композитор,1998. 432 с.

6. Armengaud J.-P. Entretiens avec Denisov: un compositeur sous le régime soviétique. Éditions Plume: Paris, 1993. 149 p.

7. Klee P. VEGAP: Album / Text J. M. F. Garcia-Bermejo. Barcelona Ediciones Poligrafa, 2007. $63 \mathrm{p}$. 


\section{Об авторе:}

Климова Наталия Викторовна, кандидат искусствоведения, доцент кафедры истории и теории музыки, Тамбовский государственный музыкальнопедагогический институт имени С.В. Рахманинова (392000, г. Тамбов, Россия), ORCID: 0000-0002-2652-3024, nkliko68@mail.ru

\section{e REFERENCES}

1. Aver'yanova O.I. Otechestvennaya muzykal'naya literatura: uchebnik dlya detskikh muzykal'nykh shkol. Chetvertyy god obucheniya [Domestic Music Literature: A Textbook for Children's Music Schools. Fourth Year of Study]. Moscow: Muzyka, 2001. 254 p.

2. Zhukova T. Audiovizual'nye tekhnologii v sfere sovremennoy akademicheskoy muzyki: tendentsii, osobennosti, problemy [Audiovisual Technologies in the Field of Modern Academic Music: Trends, Features, Problems]. Muzykal'naya zhizn' [Musical Life]. 2011. No. 7/8, pp. 88-90.

3. Klee P. Pedagogicheskie eskizy [Pedagogical Sketches]. Translated from German by N. Druzhkova; Edited by L. Monakhova; Foreword by L. Monakhova. Moscow: Publisher D. Aronov, 2005. 71 p.

4. Kholopova V.N. Muzyka kak vid iskusstva [Music as an Art Form]. 2nd Ed. Moscow: Konservatoriya, 1990. 258 p.

5. Shul'gin D.I. Priznanie Edisona Denisova. Po materialam besed [Confession of Edison Denisov. Basedon Interviews]. Moscow: Kompozitor, 1998. 432 p.

6. Armengaud J.-P. Entretiens avec Denisov: un compositeur sous le régime soviétique. Éditions Plume: Paris, 1993. $149 \mathrm{p}$.

7. Klee P. VEGAP: Album. Text J. M. F. Garcia-Bermejo. Barcelona Ediciones Poligrafa, 2007. 63 p.

About the author:

Nataliya V. Klimova, Ph.D. (Arts), Associate Professor at the Department of History and Theory of Music, Tambov State Musical Pedagogical Institute named after S.V. Rachmaninov (392000,Tambov, Russia), ORCID: 0000-0002-2652-3024, nkliko68@mail.ru 